\title{
セロオリゴ糖の簡易な調製 法
}

\author{
佐々木 堯*・田中崇*・貝沼 圭二*
}

\section{A Simple Method for Preparation of Cellooligosaccharides}

\author{
Takashi Sasaki*, TaKashi TanaKa* and KeIJi Kainuma*
}

\begin{abstract}
Cotton cellulose powder $(5 \mathrm{~g})$ was dissolved in $20 \mathrm{~m} l$ solution of conc. $\mathrm{H}_{2} \mathrm{SO}_{4}$-conc. $\mathrm{HCl}(1: 1)$ and then $60 \mathrm{~m} l$ of conc. $\mathrm{HCl}$ was added, and it was hydrolyzed partially at $20^{\circ} \mathrm{C}$ for $5 \mathrm{hr}$. The produced cellooligosaccharides were recovered by cold acetone fractionation from 70 to $95 \%$, and the yield was about $250 \mathrm{mg}$ in tatal. The cellooligosaccharides were separated to G 1, G 2, G 3, G 4 and $\mathrm{G} 5$ by paper chromatography with $n$-butanol-pyridine-water $(4: 4: 1)$ and the elution profile of the cellooligosaccharides by Bio-Gel $\mathrm{P}-4 \rightarrow \mathrm{P}-2 \rightarrow \mathrm{P}-2$ series column showed a good separation of G 1 G 8. These results show that the cellooligosaccharides prepared by this method can be used for analytical standards of paper chromatography and filtration.
\end{abstract}

(Received Apr. 6, 1979)

セルラーゼの作用機作，セルロースの䤃素分解とその 利用などの研究が最近盛んに行われているが，その研究 に必要な試薬の 1 つに標準物質としてのセロオリゴ糖が ある。さらに，セロオリゴ糖はその結合から非代謝性の 化合物であるが，水に可溶であることから最近デンプン からのオリゴ糖の利用之同様，応用的にも與味がもたれ てきている化合物である。例えばセロビオースはさわや かな甘味を有する。

このセロオリゴ糖は，セロビオース以外は市販されて おららず, 従来の調製法として報告されているのはMILLER の方法”のみである。この方法は煻液調製のために，発 煙塩酸を用いせルロースを溶解・分解後, 炭酸水素ナト リウムで中和するという煩雑な手法である。そしてこの セロオリゴ楉の分画には，大型のカーボンセライトカラ 厶を用いて大量のエタノール溶液で溶出するという時間 のかかる方法である。しかしこの方法は大量のオリゴ糖 ( 5g) を調製できる利点を有している。

しかしながら，セロオリゴ禟定標準物質として使用す

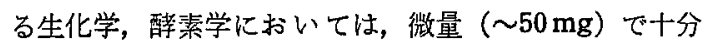
である。そこで，できるだけ簡単な操作によるオリゴ煻
の調製方法が望まれてきた。本論文では，上記の目的の ための簡単なせロオリゴ糖の調製方法を開発したので報 告する。

\section{実験方法ならびに試薬}

\section{1. セロオリゴ糖の調製}

予備実験 (実験結果の項参照)の結果, 次のとおりに した。セルロース粉末 $5 \mathrm{~g}$ を市販特級罣硫酸一源塩酸 $(1: 1)$ 溶液 $20 \mathrm{~m} l$ に加え, ガラス棒を用いて低温下 $\left(5^{\circ} \mathrm{C}\right)$ て㨨拌溶解した。10分後，この溶夜にさらに浱塩 酸 $60 \mathrm{~m} l$ を加光，㩭拌しながら $20^{\circ} \mathrm{C}, 5$ 時間放置後冷 アセトンを用いて分画を行い, 70〜95\% フセトン濃度 で析出してくる区分を分取した。この区分を小ガラス

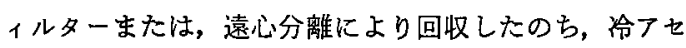
トンで洗浄し過剩の酸を除去した。ついでこの白色粉末 を小ビーカーにとり， $5 \mathrm{~m} l$ の水汇溶解したのち， $0.5 \mathrm{~N}$ 水酸化ナトリウムで $\mathrm{pH}$ を 5 6調整した。この溶液 Amberlite 1R-120(H) ついで Dowex 1(OH)の 小カラムに流し，50\% フセトン溶液で脱塩・溶出した 後, 溶出液を $5 \mathrm{~m} l$ に減圧浱縮した。このセロオリゴ糖

* 豊林水産省食品紛合研究所（干305 茨城県筑波郡谷田部町観音台 2-1-2)

National Food Research Institute, Ministry of Agriculture, Forestry and Fisheries

Kannodai 2-1-2, Yatabemachi, Ibaraki 
液中の糖含量は $251 \mathrm{mg} / 5 \mathrm{~m} l$ であり, 低温下に貯蔵し た。

\section{2. セロオリゴ糖の分画}

予備実駼（実験結果の項参照）の結果，次のとおりに した。Bio-Gel P -4 $\rightarrow \mathrm{P}-2 \rightarrow \mathrm{P}-2$ の 3 連カラム（各径 $2.5 \mathrm{~cm} \times$ 長さ $90 \mathrm{~cm})$ にセロオリ 糖液 $1 \mathrm{~m} l(50 \mathrm{mg} \mathrm{ダ}$ ルニース相当量）を注入し，水安用いて溶出した。溶出 速度はペリスタポンプにより $30 \mathrm{~m} l / \mathrm{hr}$ に調節し, フラ クションコレクターを用いて $4 \mathrm{~m} l$ ずつ分画した。分画 液の一部をとり，テクニコン自動分析器によりセロオリ ゴ糖の溶出バターンを求めた。

\section{3. 糖の定量}

全糖の定量は，フェノールー硫酸法”あるいはオルシ ノールー硫酸法")，還元糖の定量はンモギ法"により行っ た。

4. セロオリゴ糖のペーパークロマトグラフィー セロオリゴ糖を各 $20 \sim 50 \mu \mathrm{g}$ 相当量を東洋沪紙 No. $50(20 \times 20 \mathrm{~cm})$ にスポットし，nーブタノールーピリジン 一水 $(6: 4: 4)$ の溶媒系で, $30^{\circ} \mathrm{C}, 1$ 夜, 上昇法で展開 した。風乾後、フルカリ性硝酸銀法によりセロオリコ煻 を検出した。

\section{5. 試 薬}

セルロースは綿セルロース粉末（Bタイプ，200〜300 メッシュ，東洋科学株式会社製）を使用した。

Bio-Gel P-2 おょび P-4 は, Bio-Rad Laboratory 製 (U.S.A.)，200〜400 メッシニのゲルを使用した。

標準セロオリゴ糖は MILLER の方法 ${ }^{1}$ に準じて調製し た。

\section{実験結果および考察}

\section{1. セロオリゴ禟の調製法の検討}

従来の発煙塩酸一中和法にかわる簡単なセロオリゴ糖 の調製法について検討した。セルロース粉末 $5 \mathrm{~g}$ を市販 の特級浱硫酸-濃塩酸 $(1: 1)$ 溶液 $20 \mathrm{~m} l$ に加光，ガラス 棒を用いて挸䢁溶解した。10分後，この溶液にさらに濃 塩酸 $(20 \sim 60 \mathrm{ml})$ を加元，䚌拌しながら $20^{\circ} \mathrm{C} ， 5$ 時間 放置後冷アセトンを加えると 70９5\% のアセトンで白 色のセロオリゴ糖が析出してきた。これを回収・脱塩し 試料とした。

図 1 K，セルロース专溶解した硫酸一塩酸 $(1: 1)$ 溶液 にさらに塩酸量を增していった場合の生成してきたセ口 オリゴ糖のペーパークロマトグラムを示してある。

セルロースの酸部分加水分解により生成してくるせロ オリゴ糖は, 硫酸と塩酸の割合が $1: 1$ の場合はグルコ
ース(G1)，セロビオース(G2)，セロトリオース(G3)， セロテトラオース (G4) などの他に, G2 と $\mathrm{G} 3$ の間 に還元性を示す未同定のスポットが检出された。しか し，硫酸に対する塩酸の割合を高くしていくと，このス ポットは減少し硫酸：塩酸の比率が $1: 5$ 以上では検出 されなくなる。これらの試料の中には G5以上のオリ 糖も含をれているが G5，G6，G7などを良く分離する 溶媒系は現在までのところ見出されていない。これに対 しデンプンからのマルトオリゴ糖では簡笚にペーパー上 でG1から G13〈゙らいまで分離されている6)。MILLER も指適しているように，この相遠はせロオリコ糖の溶解 性に起因しているものと考えられる。

MILLER はセロオリゴ糖の調製に発煙塩酸を使用して いる゙が，この試薬は市販の濃塩酸よりもさらに比重の 重いもので現在は市販されていない。従って，市販の濃 塩酸に更に塩酸ガスを吹き込んで所定の比重の発煙塩酸 を調製する必要肪ある。セロオリゴ糖調製に発煙塩酸を 用いる理由は，七ルロースの均一な部分加水分解のため にはセルロースを溶解する必要があるが，市販の浱㸃酸 では溶解せず発洷塩酸ではじめて溶解しはじめることに よる。これに対し，著者らは取报いの困難な発煙塩酸の かかりに市販の試薬でセルロースを溶解することを梌討 し，濃硫酸と濃塩酸の組合せで代行できることを明らか にしたわけである。ここで問題になったのは硫酸：塩酸 の比率が 1:1 の時には, 図 1亿もあるように未知物質

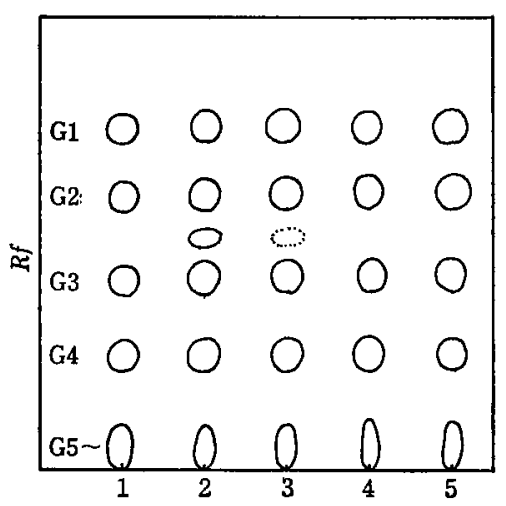

Fig. 1. Paper chromatogram of cellooligosaccharides prepared by $\mathrm{H}_{2} \mathrm{SO}_{4}-\mathrm{HCl}-$ Acetone Method

1. Standards 2 5. Cellooligasaccharides prepared by $\mathrm{H}_{2} \mathrm{SO}_{4}-\mathrm{HCl}-$ Acetone Method

2. $\mathrm{H}_{2} \mathrm{SO}_{4} 1: \mathrm{HCl} 1$

3. $\mathrm{H}_{2} \mathrm{SO}_{4} 1: \mathrm{HCl} 3$

4. $\mathrm{H}_{2} \mathrm{SO}_{4} 1: \mathrm{HCl} 5$

5. $\mathrm{H}_{2} \mathrm{SO}_{4} 1: \mathrm{HCl} 7$ 
が G 2 と G 3 の間に㭘出されたことである。この未同定 の物質はイソセロビオースようあるいは誘導体 $\left(-\mathrm{SO}_{4}\right)$ ような物質と考えられる。この物質の生成は，本研究の ためには不都合であり硫酸の割合を相対的に減少させる ことにより防ぐことができた。

生成したセロオリゴ煻の酸溶液からオリゴ糖を分離す るのに MILLER は中和法を用いているが，この方法で㤬 多量に生成した塩の処理が大変である。著者らはこの点 を改良するため簡単な有機溶媒によるセロオリコ糖の 回収法について検討し，セロオリゴ糖はフセトン沈殿に より回収することができることを明らかにした。るちろ ん MILLER 法の発煙塩酸でセロオリゴ糖液を作り，著者 らのフセトン法により回収することもできよう。

\section{2. セロオリゴ糖の分画法}

MILLER はセロオリゴ糖の分画に大型のカーボンーセラ イトカラムを用いているが，本実験では簡略化のために ゲル㴔過法によるオリゴ䌅の分画について検討した。

図 2 に示したように, Bro-Gel P-4 $\rightarrow$ P-2 $\rightarrow$ P-2 の 3 連カラム（各径 $2.5 \mathrm{~cm} \times$ 長さ $90 \mathrm{~cm}$ のサイズ）にセ ロオリゴ糖 $1 \mathrm{ml}(50 \mathrm{mg}$ グルコース相当量)を注入し， 水を用いて溶出した。溶出速度はぺリスタポンブにより $30 \mathrm{~m} l / \mathrm{hr}$ に調節し, フラタションコレタターを用いて $4 \mathrm{~m} l$ ずつ分画した。分画液の一部をとり,テクニコン自 動分析機によりセロオリゴ糖の溶出ペターンを求めた。

その結果注図 3 に示したように, G1 加ら G8 のせ口 オリゴ糖を分画することができ分離も良好であった。本 法で調製したセロオリゴ糖は G 3，G 4，G5 を主体とし ており，G6，G7，G8 と減少している。これは MILLER の方法でも同様の結果であり， G 7 以上になると急激に 溶解度が低下するためと考えられる。

分画されたセロオリゴ糖区分は，各々凍結乾燥後白色 粉末として得られ，MLLLER 法との比較ならびにぺー・ ークロマトグラフィー，D.P. 分析等により同定した。

本法と MILLER の方法との比較を表 1 にまとめてある が，カーボンーセライトカラムに対し Biol-Gel カラム

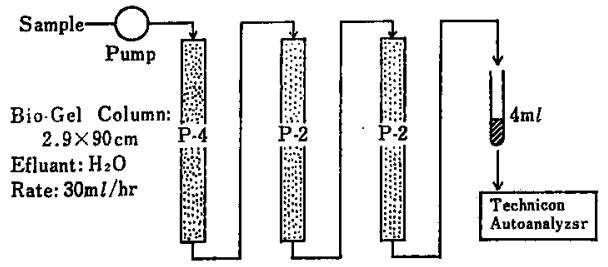

Fig. 2. Separation and analysis of cellooligasaccharides

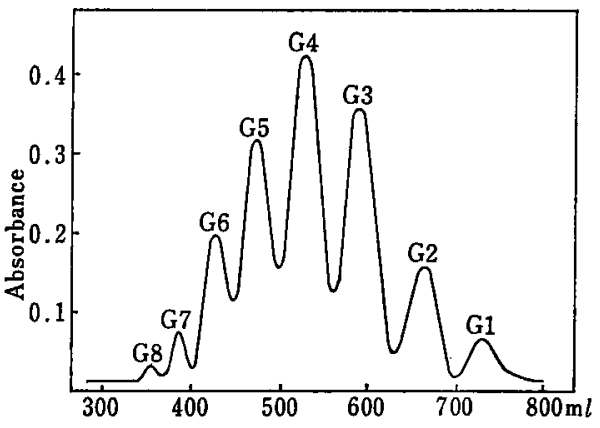

Fig. 3. Elution profile of cellooligosaccharides from Bro-Gel. P $4 \rightarrow \mathrm{P} 2 \rightarrow \mathrm{P} 2$ column

は取扱いが簡単であり，用いる溶出液で先浄するだけて 繰返し使用することができる。そして G1 から G8 ま で溶出するのに MILLER 法の 1/10 溶出液ですみ，カー ボンーセライトカラムと同様良好な分離を示している。 カラムの分離能は本条件下では $50 \mathrm{mg}$ が最適であり， これ以上の試料を流した場合は分離が墨くなるが，目的 とする区分の再クロマトにより簡単に単離できる。

本法および MILLER 法の分離可能なセロオリゴ糖は共 に G1 から G8 までであり G9 以上になると検出され なくなる。

この点セロオリゴ糖は，殿粉汃ら調製されるマルトオ リロ゙糖とは大きな遠いがある。貝沼らりは、ルトオリゴ 糖を Bio-Gel P-6 $\rightarrow$ P 2 カラムを用いて G 1 から G 25 まで分離できることを明らかにしている。

このように同じ大きさのオリ Z゙糖でも， $\alpha-1,4$-結合の ものと $\beta-1,4$-結合のもので溶解度に大きな䔔いがある のは興味深い。

以上のことから，本法は分析用セロオリゴ結（ 100

Table 1. Comparison of the Methods

\begin{tabular}{|c|c|c|}
\hline & SASAKI et $a l$ & MiLleR \\
\hline Materials & $\begin{array}{l}\text { Cellulose Powder } \\
\text { (Toyoroshi) }\end{array}$ & $\begin{array}{l}\text { Cellulose Powder } \\
\text { (Whatman) }\end{array}$ \\
\hline Acid & $\mathrm{HCl}-\mathrm{H}_{2} \mathrm{SO}_{4}$ & Fuming $\mathrm{HCl}$ \\
\hline Acid-removal & Acetone $(70-95 \%)$ & $\mathrm{NaHCO}_{3}$ \\
\hline Column & Bio-Gel P-4. P-2 & Carbon-Celite \\
\hline Eluant & $\mathrm{H}_{2} \mathrm{O}, 1 l$ & $40 \%$ Ethanol, $10 l$ \\
\hline Assay & Orcinol- $\mathrm{H}_{2} \mathrm{SO}_{1}$ & Orcinol- $\mathrm{H}_{3} \mathrm{SO}_{4}$ \\
\hline Distribution & $\mathrm{G} 1 \sim \mathrm{G} 8$ & $\mathrm{G} 1 \sim \mathrm{G} 8$ \\
\hline Character & $\begin{array}{c}\text { Analytical (10 mg } \sim) \\
\text { Semi-preparative } \\
(\sim 100 \mathrm{mg}) \\
\text { Standard reagents }\end{array}$ & Preparative $(\sim 5 \mathrm{~g})$ \\
\hline
\end{tabular}


mg）の調製に適しており，硫酸一塩酸一フセトン法によ り調製したセロオリゴ糖液はそのままぺーパークロマト グラムなどの分析用標準物として使用できる。さらに目 的により Bio-Gel P 4-P 2-P 2 カラムにより簡単にオリ ゴ糖の溶出パターンを求めることができ，同時に各々の オリゴ糖を回收し分析用に供することができる。これに 対して MILLER の方法は，大量に各々のせロオリゴ糖 ( 1 g) を調製するのに適している。

\section{要約}

セロオリゴ禟の簡易な調製法ならびにその分画法を開 発した。セルロース粉末 $5 \mathrm{~g}$ を濃硫酸一塩酸 $(1: 1) 20$ $m l$ に溶解後, 濃盐酸 $60 \mathrm{ml}$ を加え, $20^{\circ} \mathrm{C}$, 5 時間部分 加水分解したのち，冷アセトン（70 95\%分画）を用い てセロオリゴ糖を回収した。セロオリゴ糖の収量は約 $250 \mathrm{mg}$ であり，ペーパークロマト用の標準物質として 用い，更に次のゲル瀘過法により各々のオリゴ糖を調製
することができる。

セロオリゴ糖 $50 \mathrm{mg}$ を Bio-Gel P $4 \rightarrow \mathrm{P} 2 \rightarrow \mathrm{P} 2$ の 3 連カラム (各 $2.5 \times 90 \mathrm{~cm}$ ) に注入し, $30 \mathrm{~m} l / \mathrm{hr}$ の流 速で水を用いて溶出することにより， G1 から G8 8 をで のセロオリゴ桾を分離することができた。

$$
\text { 文献 }
$$

1) MiLler, G.L.: Methods in Carbohydrate Chemistry III, Cellulose, (Academic Press), 134 (1963).

2) Dubors, M., Gilles, K. A., Hamilton, J. K., Rebers, P.A. and Smith, F.: Anal. Chem., 28, 350 (1956).

3) Fernell, W.R. and King, H.K.: Analyst, 78, 80 (1953).

4) Somogyi, M.: J. Biol. Chem., 195, 19 (1952).

5) Kainuma, K., Nogami, A. and Mercier, C.: J. Chromatogr., 121, 361 (1976).

（昭和 54 年 4 月 6 日受理） 